\title{
Blood gas profile of copper-poisoned in sheep treated with ammonium tetrathiomolybdate
}

\section{Perfil de gases sanguíneos de ovinos intoxicados por cobre e tratados com tetratiomolibidato de amônio}

\author{
Pierre Castro Soares ${ }^{1}$; Marta Lizandra do Rêgo Leal ${ }^{2 *}$; Clara Satisuki Mori ${ }^{3}$; \\ Maria Claudia Araripe Sucupira ${ }^{4}$; Enrico Lippi Ortolani ${ }^{5}$
}

\begin{abstract}
The aim of this study was to evaluate the blood gas profile of experimentally copper-poisoned sheep (in the pre-hemolytic, hemolytic and post-hemolytic phases) that have been treated or not treated with ammonium tetrathiomolybdate. Ten lambs of the Santa Ines breed were divided into two groups: control and ATTM (treated (ammonium tetrathiomolibydate). The animals were submitted to increasing doses of copper sulfate until macroscopic hemoglobinuria was detected.All of the control animals from died within four days of hemolytic crisis, and one sheep from ATTM died during the treatment. There was no difference in blood gas parameters between experimental groups. Higher values of $\mathrm{pCO}_{2}$ were observed during the hemolytic crisis (HC) in both groups. The control group had higher mean values of $\mathrm{hCO}_{3}$ in the times $\mathrm{HC}$ and 2 days after hemolytic crisis $(\mathrm{dA})$ when compared with the time 15 before hemolytic crises $(\mathrm{dB})$. The sheep that were treated with ATTM presented lower values of $\mathrm{hCO}_{3}$ at $7 \mathrm{~dB}$ and higher levels at the HC. The control and ATTM groups exhibited higher values of BE during the HC. Poisoning resulted in disorder in the acid-base equilibrium, characterized by metabolic alkalosis and respiratory acidosis. Treatment with ATTM was able to reverse the changes in acid-base balance in copper poisoning sheep.
\end{abstract}

Key words: Sheep, blood gas, cooper, ammonium tetrathiomolybdate

\section{Resumo}

O objetivo desse estudo foi avaliar o perfil de gases sanguineos em ovinos experimentalmente intoxicados com cobre (fases: pré-hemoltica, hemolitica e pós-hemolitica) tratados ou não com tetratiomolibidato de amônio (ATTM). Dez cordeiros da raça Santa Inês foram divididos em dois grupos:controle (tratados com solução fisiologica a $0,9 \%$ ) e ATTM (tratados com 3,4 mg/kg de tetratiomolibidato de amonio). Os animais foram submetidos a doses crescentes de sulfato de cobre até a observação de hemoglobinúria macroscópica. Todos os animais do grupo controle morreram dentro de quatro dias após observação da hemoglobinúria, e um cordeiro do grupo ATTM morreu durante o tratamento. Não houve diferença nas varíaveis hemogasometricas entre os grupos durante o período experimental. Maiores valores da $\mathrm{pCO}_{2}$ foram observados nos dois grupos experimentais dutante a crise hemolitica (HC). O grupo controle exibiu valores mais elevados do $\mathrm{hCO}_{3}$ na $\mathrm{HC}$ e dois dias após a crise hemolitica em relação ao tempo 15 dias após a crise hemolitica. Os animais do grupo tratado com ATTM apresentaram, respectivamente,

\footnotetext{
1 Prof. Dr. Universidade Federal Rural de Pernambuco, UFRPE, Pernambuco, PE. E-mail:psoares@dmv.ufrpe.br

${ }^{2}$ Prof $^{a}$. Dr ${ }^{\mathrm{a}}$. Universidade Federal de Santa Maria, UFSM, Santa Maria, RS. E-mail: martali@usp.br

${ }^{3}$ Química, Faculdade de Medicina Veterinária e Zootecnia da Universidade de São Paulo, FMVZ-USP, São Paulo, SP. E-mail: clarasat@usp.br

${ }^{4}$ Prof $^{\mathrm{a}}$. Dr ${ }^{\mathrm{a}}$. da FMVZ-USP, São Paulo, SP. E-mail: sucupir@usp.br

${ }^{5}$ Prof. Titular da FMVZ-USP, São Paulo, SP. E-mail:ortolani@usp.br

* Author for corespondence
} 
${ }^{a}$ menores e maiores valores do $\mathrm{hCO}_{3}$ sete dias antes da crise hemolitica e durante a crise hemolitica. Os dois grupos exibiram maiores valores da $\mathrm{BE}$ na crise hemolitica. A intoxicação por cobre gerou desordem no equilibrio ácido-base, caracterizada por alcalose metabolica e acidose respiratória. $\mathrm{O}$ tratamento com ATTM foi capaz de reverter as alterações hemogasometricas em ovinos intoxicados por cobre.

Palavras-chave: Ovinos, gases sanguineos, intoxicação, cobre, tetratiomolibidato de amônia

\section{Introduction}

Copper is an essential microelement for animals. However, excessive ingestion can lead to high mortality rates in sheep (ORTOLANI; MACHADO; SUCUPIRA, 2003; ROUBIES; GIADINIS; POLIZOPOULOU, 2008). Several cumulative copper poisoning (CCP) outbreaks for this species have been reported in Brazil. (MAIORKA et al., 1998; CASTRO; CHARDULO; SZABÓ, 2007). Because most of the sheep stricken by poisoning are of great zootechnical value and the lethality is over $80 \%$, the economic losses caused by copper poisoning are quite significant (ORTOLANI; MACHADO; SUCUPIRA, 2003; ROUBIES; GIADINIS; POLIZOPOULOU, 2008).

In animals, a copper deficit can lead to deficiency, and an excess can lead to poisoning (ORTOLANI; MACHADO; SUCUPIRA, 2003; MINERVINO et al., 2009; UNDERWOOD; SUTTLE, 1999). The sheep is the domesticated species most predisposed to developing both poisoning and deficiency profiles. These profiles are associated with different speciesrelated copper metabolism pathways. Sheep exhibit difficulties in excreting copper (UNDERWOOD; SUTTLE, 1999; ORTOLANI, MACHADO; SUCUPIRA, 2003; ROUBIES; GIADINIS; POLIZOPOULOU, 2008). It is also recognized that young sheep (which are still developing) can be much more susceptible to copper poisoning because they can absorb dietary copper more efficiently than can adult sheep (SCOTT, 2002; ROUBIES; GIADINIS; POLIZOPOULOU, 2008).

The increase in CCP over the last few decades has been connected to changes in the management practices of sheep breeders that have led them to feed their flocks with diets high in copper and to use mineral salts that were made for cattle and that contain high levels of copper CPP is also associated with the feeding of sheep with concentrates which contain high levels of grain such as corn, wheat and soybeans.

The blood gas analysis is an excellent tool for the assessment of acid-base status and prognosis of diseases. The $\mathrm{pH}$ level of the body fluids, especially the fluids found in the extracellular, intravascular and intracellular spaces, must be kept balanced by the organism (HOUPT, 2006) Depending on the source, disorders of acid-base balance, acidosis or alkalosis, may be metabolic or respiratory. Under normal conditions there is a delicate balance between the respiratory and metabolic components, which determine the $\mathrm{pH}$ stability (FREITAS et al., 2010). However, apparently normal $\mathrm{pH}$ values do not discard the possibility of changes in acid-base balance (FREITAS et al., 2010).

The regulation of acid-base balance is interwoven with a rigorous and precise control of concentration of $\mathrm{H}^{+}$ion from the intracellular and extracellular space. This process is performed, primarily by three pathways that are interconnected. They are: intracellular and extracellular buffers, elimination of $\mathrm{CO}_{2}$ by the pulmonary and renal regulation of $\mathrm{H}^{+}$ and $\mathrm{HCO}_{3}$ (DRAGE; WILKINSON, 2001).

There is a wide range of diseases and metabolic disturbances that can change the acid-base balance of ruminants. Illnesses involving the urinary, digestive, respiratory and endocrine systems are particularly noteworthy. Disturbances in homeostasis and in metabolic processes are also related to the lack of a proper acid-base balance (HOUPT, 2006; MARTINELLI, 2006; FREITAS et al., 2010). As for copper poisoning in sheep there is little research 
that reported the effects of poisoning by copper in the blood gas profile of sheep, indicating a need for studies that reveal the real acid-base status in these animals. Therefore, the need for further research on this subject is addressed in this paper by evaluating the blood gas profile of experimentally copperpoisoned sheep (in the pre-hemolytic, hemolytic and post-hemolytic phases) that have been treated or not with ammonium tetrathiomolybdate.

\section{Material and Methods}

Ten six month old male Santa Ines sheep with an average body weight of $35 \mathrm{~kg}$ were used. Before the experiment, the animals spent 90 days adapting to the facilities, the environment and the food. Within the first few days, they were put into individual metabolic cages and submitted to a physical examination and worming. The cages provided access to food and water. During the adaptation period, their diet was adjusted based on the previous day's leftovers so that $20 \%$ of the unused hay could be reused. The food was provided in accordance with the demands of animal keeping. The sheep were fed a Coastcross grass hay compound diet (Cynodon dactylon) (600 grams of dry matter (MS)/head), 200 $\mathrm{g}$ of commercial sheep rations and water ad libitum. They were fed once a day, every day, throughout the experimental period. The diet contained around 11 parts per million (ppm) copper. The animal were divided into two experimental groups of five animals each: control (animals that received $0.9 \% \mathrm{NaCl}$ solution as a placebo) and ATTM (animals treated with ammonium tetrathiomolybdate [ATTM]).

All sheep were initially given orally with $3 \mathrm{mg}$ $\mathrm{Cu} / \mathrm{kg}$ Cooper sulfate (Merck Brasil, Jacarepaguá, RJ, Brazil) of body weight per day for one week. Each week, an additional $3 \mathrm{~g}$ of body weight $\mathrm{Cu} / \mathrm{kg}$ was included in the dosage until the signs of copper poisoning appeared (ORTOLANI; ANTONELLI; SARKIS, 2004). The animals were weighed weekly for dose correction. When macro-and microscopic hemoglobinuria was observed, using hemoglobin reagent strips (Labtest Diagnostic SA, Belo
Horizonte, MG, Brazil), the copper sulfate oral application was suspended. After hemoglobinuria was observed, the treatment period began. The ATTM group was treated intravenously with 3.4 $\mathrm{mg} / \mathrm{kg}$ of tetrathiomolybdate ammonia; because of its density, the ammonium tetrathiomolybdate was diluted in $20 \mathrm{~mL}$ of sterile saline solution that had previously been heated to $40^{\circ} \mathrm{C}$. Treatment was carried out once a day for the four days following the observation of hemoglobinuria. The control group was given identical doses of an isotonic saline solution via the same application method.

For the blood gas tests, 3-mL blood samples were obtained through jugular venipuncture (using a heparinized syringe). After blood collection, the syringes were properly conditioned in Styrofoam coolers that were filled with iced water and recycled ice until they could be brought to the laboratory for immediate analysis. The blood gas variables were analyzed at the following time points: $30 \mathrm{~dB}(30$ days before the hemolytic crisis), $15 \mathrm{~dB}$ (15 days before the hemolytic crisis), $7 \mathrm{~dB}$ (7 days before the hemolytic crisis), $\mathrm{HC}$ (hemolytic crisis, during macroscopic and microscopic hemoglobinuria), 1dA (24 hours after the hemolytic crisis), 2dA (48 hours after the hemolytic crisis), $3 \mathrm{dA}$ (72 hours after the hemolytic crisis), 4dA (96 hours after the hemolytic crisis), 5dA (120 hours after the hemolytic crisis), $15 \mathrm{dA}$ ( 15 days after the hemolytic crisis), and 30dA (30 days after the hemolytic crisis).

The serum copper concentration was determined using a colorimetric method with a commercial kit (Kit number 3319, Merck Brasil, Jacarepaguá, RJ, Brazil) after deproteinization of the sample, with the addition of bathocuproine sulfonate as a specific reagent for copper. The readings were made on a digital spectrophotometer (Espectofotometro model 34311, Micronal, São Paulo, SP, Brazil). The blood gas profile was evaluated by examining the blood $\mathrm{pH}, \mathrm{pCO}_{2}$ (partial pressure of blood carbon dioxide and $\mathrm{pO}_{2}$ (oxygen partial pressure of blood oxygen), as well as by making an automatic calculation of the standard level of $\mathrm{hCO}_{3}$ (blood bicarbonate concentration) beyond the $\mathrm{SO}_{2}$ (blood oxygen 
saturation) and the $\mathrm{tCO}_{2}$ (blood total carbon dioxide) and $_{\mathrm{BE}}$ (blood base excess). A blood gas analyzer was used (AVL Omni- Instrumental, Copenhagen, Denmark).

Thirty days after the hemolytic crisis ATTM group animals were euthanized (euthanasia that consisted of premedication with acepromazine hydrochloride [1mL], followed by anesthesia induction with thiopental sodium [2g] and a subsequent lethal dose of potassium cloreto [100mL]). Inductively coupled plasma atomic emission spectroscopy (ICP-AES) was used to determine the hepatic and dietary copper concentrations (concentrated and in the hay). The liver samples used to determine the hepatic levels of copper were obtained from the control animals immediately after death and from the ATTM at $30 \mathrm{dA}$.Before the reading, the liver fragments were prepared by kiln drying at $103^{\circ} \mathrm{C}$ for 24 hours and then submitted to humid digestion with nitric and perchloric acid (4:1 v/v) (KRUG et al., 1977). The hepatic and dietary copper concentrations were measured in the Application and Lasers Center (CLA) of the Institute of Energy and Nuclear Research (IPEN) in Sao Paulo, Brazil.

The data were initially submitted to an analysis of variance (F-test) using the SAS GLM procedure (SAS, 2000) and in cases where significant differences were found, the treatment means were compared by the Duncan test. Nonparametric data (BE) were submitted to analysis by the MannWhitney test. For correlation between variables used the Pearson correlation test. A regression analysis, adjusted as a function of the collection times and their respective correlation coefficients, was also performed to check the variable pair relations. The significant differences that were observed in the regression analysis were further evaluated by the F-test. For all of the statistical analyses performed, a significance level (P) of 5\% was used.

\section{Results}

The data obtained are presented in Tables 1-4. The control group exhibited copper values that were slightly higher compared with those exhibited by sheep in the ATTM group ATTM) during the HC $(\mathrm{P}<0.04)$ (Table 1). Within the control group and group treated ATTM, higher levels of copper were observed at $7 \mathrm{~dB}$ and at the $\mathrm{HC}(\mathrm{P}<0.03)$ (Table 1). The control group exhibited higher values of hepatic copper compared with the ATTM group, indicating the efficacy of ammonium tetrathiomolybdate to chelate the copper and reduce its concentrations in liver tissue (Table 2). In this study, no differences in the blood $\mathrm{pH}$ were identified for the means for the following factors: group $(\mathrm{P}>0.05)$ and time point $(\mathrm{P}>0.05)$ for the pre-hemolytic, hemolytic and post-hemolytic phases of cumulative copper poisoning (Table 3). There was no difference in the $\mathrm{pCO}_{2}$ between the groups. Comparing all times, the highest values of $\mathrm{pCO}_{2}$ were observed in $\mathrm{HC}$ and moments $4 \mathrm{~dB}$, in relation to the times $15 \mathrm{dA}, 1 \mathrm{dA}$, $2 \mathrm{dA}$ and $3 \mathrm{dA}$ for the control group (Table 3 ). The sheep treated with ATTM exhibited higher values of $\mathrm{pCO}_{2}$ in time $\mathrm{HC}$ in relation to other experimental moments, except the time $15 \mathrm{~dB}$ (Table 3). Regarding the levels of blood bicarbonate $\left(\mathrm{hCO}_{3}\right)$ the control group had higher mean values in the times $\mathrm{HC}$ and $2 \mathrm{dA}$ when compared with the time $15 \mathrm{~dB}$ (Table 4). The sheep that were treated with ATTM presented lower values of $\mathrm{hCO}_{3}$ at $7 \mathrm{~dB}$ and higher levels at the HC. There was no difference in the values of bicarbonate in the blood between the experimental groups (Table 4). The control group showed higher values of $\mathrm{BE}$ during hemolytic crisis compared to other experimental times, except for the time $30 \mathrm{~dB}$. There was no difference in the values of BE between the groups (Table 4). The sheep treated with ATTM showed higher values of $\mathrm{BE}$ at the time $\mathrm{HC}$ regarding the moments $30 \mathrm{~dB}, 15 \mathrm{~dB}, 1 \mathrm{dA}, 3 \mathrm{dA}$ and $5 \mathrm{dA}$ (Table 4). There was no difference in the values of $\mathrm{pO}_{2}, \mathrm{tCO}_{2}$ and $\mathrm{sO}_{2}$. The positive relationship that was observed between $\mathrm{hCO}_{3}$ and the $\mathrm{BE}(\mathrm{r}=0.90$; $\mathrm{P}<0,0001)$ as well as between $\mathrm{pH}$ and $\mathrm{hCO}_{3}$ ( $\mathrm{r}=$ $0.52 ; \mathrm{P}<0,0012)$, between $\mathrm{pH}$ and the $\mathrm{BE}(\mathrm{r}=0.60$; $\mathrm{P}<0,0001)$ and $\mathrm{BE}$ and $\mathrm{pCO}_{2}(\mathrm{r}=0.90 ; \mathrm{P}<0.0014)$. 
Table 1. The mean values of the serum copper concentration $(\mu \mathrm{mol} / \mathrm{L})$ of sheep from both the control) and ATTM groups during the different phases of cumulative copper poisoning.

\begin{tabular}{|c|c|c|c|c|c|c|}
\hline \multirow{3}{*}{ Groups } & \multicolumn{6}{|c|}{ Phase } \\
\hline & \multicolumn{3}{|c|}{ Pre-Hemolytic } & \multirow{2}{*}{$\frac{\text { Hemolytic }}{\text { HC }^{\ddagger}}$} & \multicolumn{2}{|c|}{ Post-Hemolytic } \\
\hline & $30 \mathrm{~dB}^{\S}$ & $15 \mathrm{~dB}$ & $7 \mathrm{~dB}$ & & $5 \mathrm{dA}^{\mathrm{f}}$ & $30 \mathrm{dA}$ \\
\hline Control & $15.2^{\mathrm{b}}$ & $22.9^{b}$ & $54.5^{\mathrm{a}}$ & $60.7^{\mathrm{Aa}}$ & & \\
\hline ATTM & $15.8^{\mathrm{b}}$ & $24.9^{\mathrm{b}}$ & $52.7^{\mathrm{a}}$ & $52.0^{\mathrm{Ba}}$ & $27.0^{\mathrm{b}}$ & $15.6^{\mathrm{b}}$ \\
\hline
\end{tabular}

$\mathrm{P}<0.05^{\mathrm{A}, \mathrm{B}}$ differences between groups

$\mathrm{P}<0.05^{\mathrm{a}, \mathrm{b}}$ differencesinto groups

+ Hemolytic crisis (HC), § days before $\mathrm{HC}$, $\uparrow$ days after $\mathrm{HC}$

Source: Elaboration of the authors.

Table 2. Individual values and general means and standard deviations of copper in liver tissue of sheep from both the control and ATTM.

\begin{tabular}{|c|c|c|}
\hline Liver & Animals & Cooper (ppm/MS) \\
\hline \multirow{6}{*}{ Control $^{(1)}$} & 1 & $1.395,2$ \\
\hline & 2 & $3.017,8$ \\
\hline & 3 & $2.911,0$ \\
\hline & 4 & $2.183,0$ \\
\hline & 5 & $2.530,0$ \\
\hline & $\mathrm{X} \pm \mathrm{S}$ & $2.407,4 \pm 588,8^{\mathrm{A}}$ \\
\hline \multirow{5}{*}{$\operatorname{ATTM}^{(2)}$} & 1 & 481,4 \\
\hline & 2 & 556,6 \\
\hline & 3 & 510,6 \\
\hline & 4 & 528,1 \\
\hline & $\mathrm{x} \pm \mathrm{s}$ & $519,1 \pm 27.3^{\text {в }}$ \\
\hline
\end{tabular}

Analyze made (1) after death and (2) 30 days after detection of hemoglobinuria.

$\mathrm{P}<0.05^{\mathrm{A}, \mathrm{B}}$ differences between groups

Source: Elaboration of the authors.

Table 3. The mean values and standard deviations of blood gas of sheep from both the control and ATTM groups during the different phases of cumulative copper poisoning.

\begin{tabular}{|c|c|c|c|}
\hline Variables & Time & & \\
\hline \multirow{12}{*}{ pH } & & \multicolumn{2}{|c|}{ Groups } \\
\hline & & Control & ATTM \\
\hline & $30 \mathrm{~dB}^{\S}$ & $7.36 \pm 0.09$ & $7.42 \pm 0.06$ \\
\hline & $15 \mathrm{~dB}$ & $7.42 \pm 0.06$ & $7.36 \pm 0.13$ \\
\hline & $7 \mathrm{~dB}$ & $7.38 \pm 0.05$ & $7.40 \pm 0.03$ \\
\hline & $\mathrm{HC} \ddagger$ & $7.41 \pm 0.05$ & $7.41 \pm 0.06$ \\
\hline & $1 \mathrm{dA}^{\top}$ & $7.43 \pm 0.03$ & $7.44 \pm 0.11$ \\
\hline & $2 \mathrm{dA}$ & $7.43 \pm 0.07$ & $7.43 \pm 0.05$ \\
\hline & $3 \mathrm{dA}$ & $7.40 \pm 0.02$ & $7.44 \pm 0.05$ \\
\hline & $4 \mathrm{dA}$ & $7.40 \pm 0.01$ & $7.41 \pm 0.05$ \\
\hline & $5 \mathrm{dA}$ & - & $7.40 \pm 0.03$ \\
\hline & $15 \mathrm{dA}$ & - & $7.41 \pm 0.01$ \\
\hline
\end{tabular}


continuação

$30 \mathrm{dA}$

$$
\mathrm{pCO}_{2}(\mathrm{mmHg})
$$

$30 \mathrm{~dB}^{\S}$
$15 \mathrm{~dB}^{-}$
$7 \mathrm{~dB}$
$\mathrm{HC}$
$1 \mathrm{dA}^{\ddagger}$
$2 \mathrm{dA}$
$3 \mathrm{dA}$
$4 \mathrm{dA}$
$5 \mathrm{dA}$
$15 \mathrm{dA}$
$30 \mathrm{dA}$

$7.41 \pm 0.06$
$43.4 \pm 8.0^{\mathrm{b}}$

$45.2 \pm 8.7^{\mathrm{ab}}$

$40.8 \pm 6.4^{\mathrm{b}}$

$47.5 \pm 5.8^{\mathrm{a}}$

$43.5 \pm 7.0^{\mathrm{b}}$

$43.4 \pm 8.1^{\mathrm{b}}$

$39.9 \pm 7.2^{\mathrm{b}}$

$42.1 \pm 3.0^{\mathrm{b}}$

$41.0 \pm 7.1^{\mathrm{b}}$

$42.7 \pm 6.3^{\mathrm{b}}$

$39.0 \pm 8.4^{\mathrm{b}}$

${ }^{\S}$ days before the hemolytic crisis; "hemolytic crisis (macroscopic hemoglobinuria); ${ }^{\top}$ days after hemolytic crisis. $\mathrm{P}<0.05^{\mathrm{a}, \mathrm{b}}$ differences within the group

Source: Elaboration of the authors.

Table 4. Mean values and standard deviations of blood gas of sheep from both the control and ATTM groups during the different phases of cumulative copper poisoning.

\begin{tabular}{|c|c|c|c|}
\hline Variables & Time & & \\
\hline \multirow{4}{*}{$\mathrm{hCO}_{3}(\mathrm{mmol} / \mathrm{L})$} & & \multicolumn{2}{|c|}{ Groups } \\
\hline & & Control & ATTM \\
\hline & $30 \mathrm{~dB}^{\S}$ & $26.5 \pm 3.2^{\mathrm{ab}}$ & $27.2 \pm 2.1^{\mathrm{ab}}$ \\
\hline & $15 \mathrm{~dB}$ & $24.5 \pm 2.0^{\mathrm{b}}$ & $26.5 \pm 1.7^{\mathrm{ab}}$ \\
\hline & $7 \mathrm{~dB}$ & $27.2 \pm 5.4^{\mathrm{ab}}$ & $23.4 \pm 3.1^{\mathrm{b}}$ \\
\hline & $\mathrm{HC} *$ & $29.5 \pm 5.3^{\mathrm{a}}$ & $29.0 \pm 3.0^{\mathrm{a}}$ \\
\hline & $1 \mathrm{dA} \pi$ & $27.0 \pm 4.7^{\mathrm{ab}}$ & $27.4 \pm 8.9^{\mathrm{ab}}$ \\
\hline & $2 \mathrm{dA}$ & $30.3 \pm 11.0^{\mathrm{a}}$ & $27.4 \pm 5.9^{\mathrm{ab}}$ \\
\hline & $3 \mathrm{dA}$ & $27.0 \pm 5.6^{\mathrm{ab}}$ & $26.6 \pm 5.0^{\mathrm{ab}}$ \\
\hline & $4 \mathrm{~dB}$ & $26.0 \pm 2.5^{\mathrm{ab}}$ & $27.4 \pm 3.7^{\mathrm{ab}}$ \\
\hline & $5 \mathrm{~dB}$ & - & $25.0 \pm 4.7^{\mathrm{ab}}$ \\
\hline & $15 \mathrm{~dB}$ & - & $27.8 \pm 2.5^{\mathrm{ab}}$ \\
\hline & $30 \mathrm{~dB}$ & - & $26.6 \pm 3.7^{\mathrm{ab}}$ \\
\hline BE (mmEq/L) & $30 \mathrm{~dB}^{\S}$ & $3.0 \pm 2.3^{\mathrm{ab}}$ & $2.1 \pm 1.8^{\mathrm{b}}$ \\
\hline & $15 \mathrm{~dB}$ & $1.3 \pm 3.1^{\mathrm{b}}$ & $1.6 \pm 3.0^{\mathrm{b}}$ \\
\hline & $7 \mathrm{~dB}$ & $2.3 \pm 6.8^{b}$ & $3.2 \pm 3.7^{\mathrm{ab}}$ \\
\hline & $\mathrm{HC}^{*}$ & $4.6 \pm 5.2^{\mathrm{a}}$ & $4.1 \pm 3.3^{\mathrm{a}}$ \\
\hline & $1 \mathrm{dA}$ & $1.5 \pm 6.7^{\mathrm{b}}$ & $2.1 \pm 7.1^{\mathrm{b}}$ \\
\hline & $2 \mathrm{dA}$ & $1.1 \pm 3.0^{\mathrm{b}}$ & $2.8 \pm 2.7^{\mathrm{ab}}$ \\
\hline & $3 \mathrm{dA}$ & $0.9 \pm 6.1^{\mathrm{b}}$ & $1.5 \pm 5.9^{b}$ \\
\hline & $4 \mathrm{~dB}$ & $1.1 \pm 3.0^{\mathrm{b}}$ & $2.8 \pm 2.7^{\mathrm{ab}}$ \\
\hline & $5 \mathrm{~dB}$ & - & $1.7 \pm 4.7^{\mathrm{b}}$ \\
\hline & $15 \mathrm{~dB}$ & - & $2.6 \pm 2.0^{\mathrm{ab}}$ \\
\hline & $30 \mathrm{~dB}$ & - & $2.8 \pm 2.7^{\mathrm{ab}}$ \\
\hline
\end{tabular}

${ }^{\S}$ days before the hemolytic crisis; ${ }^{*}$ hemolytic crisis (macroscopic hemoglobinuria); ${ }^{\circledR}$ days after hemolytic crisis. $\mathrm{P}<0.05^{\text {a,b }}$ differences within the group

Source: Elaboration of the authors. 


\section{Discussion}

The animals of both groups showed higher values of plasma copper in time $\mathrm{HC}$ and $1 \mathrm{dA}$, indicating that the CCP induction protocol was effective and that it is possible to imitate the clinical characteristics that are induced naturally by ingestion (as well as the consequent hepatic copper accumulation over time). In cases of natural copper poisoning, it is known that the hemolytic crisis is determined by excessive hepatic copper and by the liberation of free copper into the blood stream, which alters several physiological systems and leads to the animal's death (SCOTT, 2002; CASTRO; CHARDULO; SZABÓ, 2007; ROUBIES; GIADINIS; POLIZOPOULOU, 2008). High levels of serum copper, especially during the onset of an $\mathrm{HC}$, caused a sequence of chain reactions that triggered intense clinical and organic alterations in the subject animals of this study. All of the untreated sheep died within five days. These results are consistent with the observation of Roubies, Giadinis and Polizopoulou (2008). That sheep with chronic copper poisoning (if not treated quickly and appropriately) die within 2-5 days because of an $\mathrm{HC}$ and renal and liver failure. Of the five animals treated with ATTM, four survived until the end of the experiment.

The hemolytic process has a considerable influence on the copper poisoning of animals because they can lose $50 \%$ to $75 \%$ of their erythrocytes (ORTOLANI; MACHADO; SUCUPIRA, 2003) causing severe anemia (CASTRO; CHARDULO; SZABÓ, 2007; ROUBIES; GIADINIS; POLIZOPOULOU, 2008). As a compensation mechanism, the organism has the ability to create a greater peripheral vascular resistance, allowing an effective circulatory volume on the microcirculation level to try to maintain cardiac output (HOUPT, 2006; KANEKO; HARVEY; BRUSS, 2008). However, over time, there is an organic imbalance between the impaired renal and hepatic function, as well as changes in the electrolyte and acid- base balance.
The hemolytic profile inhibits the animal's ability to regulate base excess through the $\mathrm{CO}_{2}$ reaction, leading to an increase of the BE. In this experiment, there was a significant positive relation between both parameters. These observations are valuable to our understanding of the physiopathology of sheep copper poisoning because they are the first of their kind to be published.

The profiles of the $\mathrm{pCO}_{2}, \mathrm{hCO}_{3}$ and $\mathrm{BE}$ (as well as the numeric analysis of the $\mathrm{pH}$ values that were higher during the $\mathrm{HC}$ ) in the both groups indicate that the animals showed a mild profile of metabolic alkalosis and respiratory acidosis. However, apparently normal $\mathrm{pH}$ values do not discard the possibility of changes in acid-base balance (FREITAS et al., 2010). This finding was also observed by Morgado et al. (2007). Respiratory acidosis or hypercapnia (a $\mathrm{pCO}_{2}$ increase) occurs when carbon dioxide production $\left(\mathrm{CO}_{2}\right)$ surpasses its excretion through the lungs (LEMOS; RANGEL; OSÓRIO, 1997; FREITAS et al., 2010). The decrease of $\left[\mathrm{H}^{+}\right]$that follows metabolic alkalosis stimulates chemoreceptors that are responsible for a decrease in alveolar ventilation. Hypoventilation (which is observed as a decrease in respiratory frequency) maintains the $\mathrm{pH}$ as the plasma concentration of $\mathrm{hCO}_{3}$ increases (DIBARTOLA, 2000; ROSE; POST, 2001; KANEKO; HARVEY; BRUSS, 2008).

The respiratory frequency during the $\mathrm{HC}$ indicated a hypoventilation condition and was significantly lower $(\mathrm{P}<0.001)$ than during the prehemolytic phase (20 breaths per minute (breaths$\mathrm{min}$ ) in the control group and 21.60 breaths-min in the group treated with ATTM); during the HC, the animals exhibited 17.70 breaths-min in the control group and 17.60 breaths-min in the ATTM group. Upon treatment with ATTM, the animals returned to a normal respiratory frequency by the $15 \mathrm{dA}$ time point (20 breaths-min), indicating a positive response to the therapy that was presumably due to the chelating effect on circulatory copper, which reduced its deleterious effects on the animal. 
According to Houpt (2006) in respiratory acidosis situations, buffering systems respond immediately; however, the response is neither complete nor long lasting. Either the cause must be corrected or acidosis will continue. In the group treated whit ATTM, this profile was longwise analogous at baseline because the copper chelating effect provided satisfactory clinical improvement. During the metabolic alkalosis compensation that can be observed in copper-poisoned sheep, the organism lowers its respiratory frequency to raise the $\mathrm{pCO}_{2}$ in the blood; this profile was observed in other experiments that used the same model to induce CCP (ORTOLANI; ANTONELLI, SARKIS, 2004).

As Kaneko, Harvey and Bruss (2008) describes, it is extremely hard to induce a metabolic alkalosis profile when there is no depletion of volume or renal dysfunction; this difficulty indicates that copper poisoning causes significant changes in both renal function and blood volume because of the presence of significant blood lysis that compromises the circulatory dynamics and results in possible hypovolemic shock. Hemolisys and hypercupremia may overload the renal tubular epithelium with hemoglobin, cooper and iron and lead to cell death. In cases of renal failure, which have been identified by evaluating several variables of renal function in the same animals tested here, this risk is especially important. Decreased bicarbonate filtration by the glomeruli is followed by an increase in reabsorption, causing a resultant increase in the bicarbonate concentration of the blood and leading to a state of alkalemia (HOUPT, 2006). The kidney regulates sodium bicarbonate metabolism, keeping its serum concentration stable (CONSTABLE, 1999; ROSE; POST, 2001; MARTINELLI, 2006). Therefore, the physiological response of the organism to metabolic alkalosis is to increase $\mathrm{pCO}_{2}$ so that each $10 \mathrm{mEq} / \mathrm{L}$ bicarbonate increase corresponds to $6 \mathrm{mmHg} \mathrm{pCO}_{2}$ increase. A moderate and positive relation between $\mathrm{pCO}_{2}$ and $\mathrm{hCO}_{3}$ blood concentration was observed in this study.
Renal failure may be considered to be important to the cause of death in sheep whit CCP. The increase of these indicators in the blood suggests a blood buffers accumulation tendency that arises from a flaw in the renal system at the time of death. Because the BE indirectly indicates the quantity of buffers in the blood, its relation with $\mathrm{hCO}_{3}$ has shown that more positive $\mathrm{BE}$ values lead to a greater accumulation of buffers in the system, presenting a metabolic alkalosis profile (HOUPT, 2006; KANEKO; HARVEY; BRUSS, 2008) Kidneys function to keep the internal environment stable. For this reason, they excrete water, promote ion exchange and keep the organism balanced. Renal tubules secrete $\mathrm{H}^{+}$ions in the tubular urine, and for each mole of secreted acid, a mole of bicarbonate (base) appears in the blood (CONSTABLE, 1999; MARTINELLI, 2006). Based on the factors that influence bicarbonate renal reabsorption, Dibartola (2000) states that because the glomerular filtration rate and extracellular fluid volume are constant, the quantity of $\mathrm{HCO}_{3}$ reabsorbed by the kidney will be equivalent to the filtrated quantity. Therefore, during renal dysfunction caused by $\mathrm{CCP}$, Morgado et al. (2007) observed that $\mathrm{hCO}_{3}$ seems to exhibit a minimum tubular concentration, causing $\mathrm{hCO}_{3}$ renal reabsorption to be quite different from sodium reabsorption.

During the renal response to metabolic alkalosis in healthy animals, the kidneys are able to effectively and quickly excrete alkalis. Metabolic alkalosis persists only when the renal excretion of $\mathrm{HCO}_{3}$ is damaged. This damage can be caused by a reduction in the glomerular filtration rate (diminished $\mathrm{HCO}_{3}$ in the filtrate), a high administration rate of alkalis or by sodium retention of the kidneys in the presence of a relative deficit of chlorine (DIBARTOLA, 2000; MARTINELLI, 2006). The real compensation for alkalosis depends on the renal system and $\mathrm{hCO}_{3}$ excretion (HOUPT, 2006). It is apparent that copper poisoning in sheep affects renal dynamics and the acid-base profile. 


\section{Conclusions}

Cumulative copper poisoning in sheep leads to metabolic and respiratory disturbances that are characterized metabolic alkalosis and respiratory acidosis. ATTM treatment caused a gradual improvement in the blood gas profile and clinical status of sheep that had been experimentally poisoned by copper.

\section{Committee of ethics and biosafety}

This work was carried out according to the principles of the commission on bioethics of the Faculdade de Medicina Veterinaria and Zootecnia at the University of São Paulo (Number 242/2005).

\section{Acknowledgment}

American Journal Expert team for editing of the article.

\section{References}

CASTRO, M. B.; CHARDULO, L. A. L.; SZABÓ, M. P. J. Copper toxicosis in sheep fed dairy cattle ration in São Paulo, Brazil. Arquivos Brasileiros de Medicina Veterinária e Zootecnia da UFMG, Belo Horizonte, v. 59, n. 1, p. 246-249, 2007.

CONSTABLE, P. D. Clinical assessment of acid-base status. Veterinary Clinical North American: Food Animal Practice, EUA, v. 15, n. 3, p. 447-471, 1999.

DIBARTOLA, S. P. Fluid therapy in small animal practice. 2. ed. Philadelphia: WB Saunders Company, $2000.680 \mathrm{p}$.

DRAGE, S.; WILKINSON, D. Acid-base balance. Pharmacology, Switzerland, v. 3, n. 12, p. 1-13, 2001.

FREITAS, M. D.; FERREIRA, M. G.; FERREIRA, P. M.; CARVALHO, A. U.; LAGE, A. P.; HEINEMANN, M. B.; FACURY FILHO, E. J. Equilíbrio eletrolítico e ácido-base em bovinos. Ciência Rural, Santa Maria, v. 40, n. 12, p. 2608-2615, 2010.

HOUPT, M. Equilibrio ácido-básico. In: SWENSON, M. J.; REECE, W. Dukes fisiologia dos animais domésticos. 3. ed. Rio de Janeiro: Guanabara Koogan, 2006. p. 147160.
KANEKO, J. J.; HARVEY, J. W.; BRUSS, M. L. Clinical biochemistry of domestic animals. 3. ed. New York: Academic Press, 2008. 896 p.

KRUG, F. J.; BERGAMIM FILHO, H.; ZAGATTO, E. A. G.; JORGENSEN, S. S. Rapid determination of sulphate in natural waters and plant digests by continuous flow injection turbidimetry. Analist, London, v. 102, n. 1, p. 503-508, july 1977 .

LEMOS, R. A. A.; RANGEL, J. M. R,; OSÓRIO, A. L. A. R. Alterações clínicas, patológicas e laboratoriais na intoxicação crônica por cobre em ovinos. Ciência Rural, Santa Maria, v. 27, n. 3, p. 457-463, 1997.

MAIORKA, P. C.; MASSOCO, C. O.; ALMEIDA, S. D. B.; GORNIAK, S. L.; DAGLI, M. L. Z. Copper toxicosis in sheep: a case report. Veterinary Human Toxicology, Manhattan, v. 40, n. 2, p. 99-100, 1998.

MARTINELLI, R. Equilíbrio ácido-básico e hidroeletrolítico In: PENILDO, S. Farmacologia. Rio de Janeiro: Guanabara Koogan, 2006. p. 711-716.

MINERVINO, A. H. H.; BARRÊTO JÚNIOR, R. A.; FERREIRA, R. N. F.; RODRIGUES, F. A. M. L.; HEADLEY, S. A.; MORI, C. S.; ORTOLANI, E. L. Clinical observations of cattle and buffalos with experimentally induced chronic copper poisoning. Research Veterinary Science, Oxford, v. 87, n. 3, p.473478, 2009.

MORGAdO, A. A.; AUGUSTO, C. F. B.; SOUZA, F. N.; NUNES, G. R.; WEIGEL, R. A.; MORI, C. S.; SUCUPIRA, M. C. A. Avaliação da hemogasometria de ovinos intoxicados por cobre e tratados com tetratiomolibdato e/ou vitaminas antioxidantes. In: CONBRAVET, 34.; CONPAVET, 7.; CONGRESSO DO COLÉGIO BRASILEIRO DE AQÜICULTURA, 5.; ENCONTRO DAS ENTIDADES DE CLASE - CRMV/ SP, 8.; CONFERÊNCIA ANUAL DA SOCIEDADE PAULISTA DE MEDICINA VETERINÁRIA, 62., 2007, Santos. Anais...Santos: Sociedade Brasileira de Medicina Veterinária, 2007. 1 CD-ROM.

ORTOLANI, E. L.; ANTONELLI, A. C.; SARKIS, J. E. Acute copper poisoning from a copper sulfate footbath. Veterinary Human Toxicology, Manhattan, v. 46, n. 6, p. 315-318, 2004.

ORTOLANI, E. L.; MACHADO, C. H.; SUCUPIRA, M. C. A. Assessment of some clinical and laboratory variables for early diagnosis of accumulative copper poisoning in sheep. Veterinary Human Toxicology, Manhattan, v. 45, n. 6, p. 289-293, 2003.

ROSE, D. B.; POST, T. W. Clinical physiology of acid base and electrolyte disorders. 5. ed. New York: Mcgraw Hill, 2001, 992 p. 
ROUBIES, N.; GIADINIS, N. D.; POLIZOPOULOU, Z. A retrospective study of chronic copper poisoning in 79 sheep flocks in Greece (1987-2007). Journal Veterinary Pharmacology Therapeutics, Raleigh, v. 31, n. 2, p. 181183, 2008.

SAS Institute. SAS user's guide. Statistical Analysis Systems Institute, Inc., Cary, NC, 2000.
SCOTT, P. R. Copper toxicity. In: PUGH, D. G. Sheep and goat medicine. London: Manson Publishing, 2002. p. 293-295.

UNDERWOOD, E. J.; SUTTLE, N. F. The mineral nutrition of livestock. Wallingford: Cabi Publishing, 1999. $614 \mathrm{p}$. 